\title{
Optimization of Cultural Conditions for Production of Extracellular Polymeric Substances (EPS) by Serpentine Rhizobacterium Cupriavidus pauculus KPS 201
}

\author{
Arundhati Pal ${ }^{1}$ and A. K. Paul ${ }^{2}$ \\ ${ }^{1}$ Department of Botany, Serampore College, 9 William Carey Road, Serampore, Hooghly, West Bengal 712 201, India \\ ${ }^{2}$ Microbiology Laboratory, Department of Botany, University of Calcutta, 35 Ballygunge Circular Road, Kolkata 700 019, India
}

Correspondence should be addressed to Arundhati Pal; arundhatipalcu@gmail.com

Received 30 March 2013; Revised 10 October 2013; Accepted 11 October 2013

Academic Editor: Cornelia Vasile

Copyright (C) 2013 A. Pal and A. K. Paul. This is an open access article distributed under the Creative Commons Attribution License, which permits unrestricted use, distribution, and reproduction in any medium, provided the original work is properly cited.

\begin{abstract}
Extracellular polymeric substances (EPS) are complex biopolymers produced by a wide array of microorganisms for protection against dessication, aggregation, adhesion, and expression of virulence. Growth associated production of EPS by Ni-resistant Cupriavidus pauculus KPS 201 was determined in batch culture using sodium gluconate as the sole carbon source. The optimum $\mathrm{pH}$ and temperature for EPS production were 6.5 and $25^{\circ} \mathrm{C}$, respectively. Optimal EPS yield $(118 \mu \mathrm{g} / \mathrm{mL})$ was attained at $0.35 \%$ $\mathrm{Na}$-gluconate after $72 \mathrm{~h}$ of growth. Cupriavidus KPS 201 cells also utilized glutamate, acetate, pyruvate, fumarate, malate, malonate, formate, citrate, and succinate for EPS production. Although EPS production was positively influenced by the increase of nitrogen and phosphate in the growth medium, it was negatively influenced by nickel ions. Compositional analysis of the purified EPS showed that it is a homopolymer of rhamnose containing uronic acid, protein, and nucleic acid. Presence of lipids was also detected with spectroscopy. Non-destructive EPS mediated biofilm formation of KPS 201 was also visualized by epifluorescence microscopy.
\end{abstract}

\section{Introduction}

Extracellular polymeric substances (EPS) are biosynthetic polymers of microbial origin produced in natural as well as artificial environments by single species or in heterogeneous communities. Irrespective of their origin, EPS are localized at or outside the bacterial cell surface and composed of a variety of high molecular weight organic macromolecules such as polysaccharides, proteins, nucleic acids, and phospholipids [1]. These exopolymers result from microbial processes like active secretion, shedding of cell surface materials, cell lysis, and adsorption from the environment. Based on their physical state, EPS can be distinguished as bound and soluble forms. The bound EPS include microbial sheaths, capsular polymers, condensed gel, and so forth while the soluble EPS include soluble macromolecules, colloids and slimes. According to the metabolism of bacterial cells, the soluble EPS are considered to be actively secreted by bacteria and are biodegradable, while the bound ones remain attached to active and inert biomass or are molecules resulting from cell lysis.

The production of EPS by bacteria in culture depends on phases of growth, nutritional status, and the environmental conditions. The production of water-soluble EPS by Rhodopseudomonas acidophila was influenced by the C:N ratio and polymer production was found to be dependent on the nature of carbon sources used [2]. Similarly, in anaerobically growing Shewanella spp., the terminal electron acceptors were found to influence the quantity and composition of capsular exopolymers. Enhanced production of EPS was induced under stressful culture conditions in Enterobacteriaceae members where compositional variation was noted due to varying proportions of different polysaccharides synthesized within the biofilm. However, for a number of bacterial species, increased EPS synthesis was found to be genetically controlled and differentially expressed genes in biofilm state regulate its composition and development. 
EPS are considered to be the key components that determine the structural and functional integrity of microbial aggregates (cohesion) and for anchoring the biofilms to the substratum (adhesion). A large amount of work has been conducted on characterizing the EPS of various pure and mixed cultures [3, 4], activated sludge [5], biogranules [6], and biofilm $[7,8]$. The EPS may not be essential for growth and viability in free-living bacterial cultures but protect cells from hostile environments. They are also involved in the degradation of particulate substances, sorption of heavy metals, leaching of minerals from sulphidic ores and biocorrosion, thus aiding in heavy metal bioremediation $[9,10]$.

Cupriavidus pauculus KPS 201 is a Ni-resistant rhizobacterium isolated from nickel percolated serpentine outcrops of Andaman Islands, India [11]. The bacterium was found to accumulate intracellular biopolymer, the polyhydroxyalkanoates under nutrient limited conditions as well under metal stress [12]. The aim of our present study was to evaluate whether this bacterium also produces extracellular polymeric substances and also to elucidate the influence of metal ions on polymer production.

\section{Materials and Methods}

2.1. Bacterial Strain and Cultural Conditions. Cupriavidus pauculus KPS 201 (MTCC 6280; GeneBank Accession no. AM418462), used throughout the present study, was previously isolated from rhizosphere of Rinorea bengalensis, a Nihyperaccumulator growing in serpentine outcrops of Saddle hills in north Andaman Islands, India [11]. The organism was grown on slopes of Tryptic soy agar medium at $28^{\circ} \mathrm{C}$ for $24 \mathrm{~h}$ and regularly subcultured at 15-day interval.

2.2. Growth and EPS Production. Production of extracellular polymeric substances (EPS) by Cupriavidus KPS 201 cells was determined during growth in batch culture using Trisminimal medium supplemented with sodium gluconate as the sole carbon source. The low phosphate Tris-buffered minimal medium $(\mathrm{pH} 7.0 \pm 0.2)$ contained $(\mathrm{g} / \mathrm{L})$ Tris-base 6.06, $\mathrm{NaCl} 4.68, \mathrm{KCl} 1.49, \mathrm{NH}_{4} \mathrm{Cl} 1.07, \mathrm{NaSO}_{4} 0.43, \mathrm{MgSO}_{4} \cdot 6 \mathrm{H}_{2} \mathrm{O}$ $0.2, \mathrm{CaCl}_{2} \cdot 2 \mathrm{H}_{2} \mathrm{O} 0.03, \mathrm{Na}_{2} \mathrm{HPO}_{4} \cdot 12 \mathrm{H}_{2} \mathrm{O} 0.02$, and $0.4 \% \mathrm{Na}-$ gluconate. Erlenmeyer flasks $(250 \mathrm{~mL})$ containing $50 \mathrm{~mL}$ media were inoculated with $18 \mathrm{~h}$ grown bacterial culture and agitated on a rotary shaker $(120 \mathrm{rpm})$ at $28^{\circ} \mathrm{C}$ for $76 \mathrm{~h}$. Samples were withdrawn at definite time intervals for determination of cell number and EPS production. Growth was estimated by total count method following centrifugation and washing twice in normal saline. The total number of cells in $1 \mathrm{~mL}$ of culture was estimated using a haemocytometer (Neubauer, Fein-Optik Jena, Germany) and a phase contrast microscope (Zeiss Winkel Model no. 148786, Germany).

2.3. Estimation of EPS. The fermented medium was first centrifuged $\left(10,000 \times \mathrm{g}, 4^{\circ} \mathrm{C}\right.$ for $\left.10 \mathrm{~min}\right)$ to separate the supernatant and cell pellet. The soluble EPS in the supernatant was precipitated with 2 volumes of prechilled acetone, kept overnight at $4^{\circ} \mathrm{C}$ and further separated by centrifugation $\left(12,000 \times \mathrm{g}, 4^{\circ} \mathrm{C}, 20 \mathrm{~min}\right)$. Subsequently, the precipitated EPS was dissolved in distilled water and quantified following the method of Dubois et al. [13]. To $1 \mathrm{~mL}$ of EPS solution, $1 \mathrm{~mL}$ of $5 \%(\mathrm{w} / \mathrm{v})$ phenol solution was added and mixed thoroughly. To the reaction mixture, $5 \mathrm{~mL}$ of concentrated $\mathrm{H}_{2} \mathrm{SO}_{4}$ was purged in and the optical density was measured at $490 \mathrm{~nm}$. The amount of EPS was determined from the calibration curve using glucose as the standard.

2.4. Purification and Compositional Analysis of EPS. The crude EPS thus obtained was purified by repeated dissolution in sterile distilled water and reprecipitation by prechilled acetone. The precipitate was lyophilized and the white powdered polymer obtained was analyzed. Total sugar content was estimated following the anthrone method of Dubois et al. [13] using glucose as standard. Estimation of sugar monomers was achieved by gas chromatography (Shimadzu GC-17A, Japan) following methanolysis of EPS. Total protein content was estimated by Folin-phenol reagent using bovine serum albumin as standard [14]. Nucleic acid was estimated by measuring the absorbance at 260 and $280 \mathrm{~nm}$ using purified DNA sample as standard. Quantitative estimation of the uronic acids was spectrophotometrically performed following the method of Blumenkrantz and Asboe-Hansen [15].

2.5. FTIR Analysis. The Fourier transform infrared (FTIR) spectra of the purified EPS were recorded in a Perkin Elmer RX-1 FTIR spectrometer. The samples prepared as KBr pellets were scanned from 500 to $4000 \mathrm{~cm}^{-1}$.

2.6. Staining and Visualization of EPS with Fluorescently Labeled Lectins. The lectin staining technique based on the method of Sizemore et al. [16] was used for visualization of EPS production by Cupriavidus KPS 201 cells. Lectin was dissolved in phosphate buffered saline (PBS) containing, in grams per liter, $\mathrm{NaCl}, 4, \mathrm{KCl}, 0.1, \mathrm{Na}_{2} \mathrm{HPO}_{4} 2 \mathrm{H}_{2} \mathrm{O}, 0.72$, and $\mathrm{KH}_{2} \mathrm{PO}_{4}, 0.1$, adjusted to $\mathrm{pH}$ 7.4. Sterile glass slides were immersed in bacterial suspension kept in Petri dishes for 37 days at $28^{\circ} \mathrm{C}$ for cell attachment and biofilm formation. Bacterial biofilms prepared on glass surface were washed with PBS once and covered with $50 \mu \mathrm{L}$ DAPI solution $(0.01 \%)$ for $10 \mathrm{~min}$ in the dark. The supernatant was removed, washed once with PBS, and stained with $50 \mu \mathrm{L}$ fluorescein isothiocyanate-labeled lectin concanavalin A $(0.1 \mathrm{~g} / \mathrm{L})$ for 4 min in the dark. Finally, the slide was washed with $1 \mathrm{~mL}$ PBS and $1 \mathrm{~mL}$ sterile distilled water and dried before observation under epifluorescence microscope (Carl Ziess).

2.7. Statistical Analysis. All experiments were carried out in triplicate and results represent mean \pm standard error.

\section{Results and Discussion}

3.1. Growth Associated Production of EPS. Cells of Cupriavidus pauculus KPS 201 produced extracellular polymeric substance during growth in Tris-buffered minimal medium using sodium gluconate as the sole carbon source. Various 
physical and chemical procedures for isolation of EPS were screened, amongst which centrifugation at $12,000 \times \mathrm{g}$ for $20 \mathrm{~min}$ at $4^{\circ} \mathrm{C}$ was found to be most suitable. Time course of growth revealed that EPS production started at late logarithmic phase and continued to increase till late stationary phase (Figure 1). The medium $\mathrm{pH}$ turned alkaline with growth and remained 7.7 after $76 \mathrm{~h}$ of incubation.

3.2. Optimization of Cultural Conditions for EPS Production. The optimum $\mathrm{pH}$ and temperature for EPS production during growth of KPS 201 cells were 6.5 and $25^{\circ} \mathrm{C}$, respectively. However, the optimum conditions do not coincide with the optimum conditions for growth of Cupriavidus KPS 201 cells (Figure 2). Gradual increase in carbon source (Na-gluconate) from 0 to $0.5 \%$ led to steady increase in cell number along with EPS yield (Figure 3). However, growth attained a maximum at $0.3 \%$ gluconate and optimum EPS yield $(118 \mu \mathrm{g} / \mathrm{mL})$ was attained at $0.35 \%$ gluconate after $72 \mathrm{~h}$ growth. A similar phenomenon was observed by Sheng et al. [2], who reported that an adequate amount of carbohydrate source was essential for the EPS production by Rhodopseudomonas acidophila. EPS production by Ralstonia eutropha and Pseudomonas sp. was also enhanced in the presence of sufficient carbon sources [17].

Cupriavidus KPS 201 cells were tested for their ability to utilize nine different carbon sources like glutamate, acetate, pyruvate, fumarate, malate, malonate, formate, citrate, and succinate (as sodium salts) for EPS production apart from Na-gluconate. Amongst all carbon sources used (at $0.4 \%$ $\mathrm{w} / \mathrm{v})$, EPS yield was the highest when cells grew in sodium glutamate and EPS production was found to increase by $25.2 \%$ in case of glutamate grown cells $(132.3 \mu \mathrm{g} / \mathrm{mL})$ than those in Na-gluconate $(105.6 \mu \mathrm{g} / \mathrm{mL})$ (Table 1). However, cells failed to show any visible growth in presence of sodium malate and formate and hence produced no extracellular polymer. Different species of Rhizobium and Agrobacterium have also been reported to utilize various monosaccharides, disaccharides, polysaccharides as well as mannitol, glutamate, succinate, and so forth, for production of exopolysaccharides [18].

The concentration of nitrogen has a profound influence on production of EPS by the bacterium and growth as well as EPS production increased with increase in nitrogen content in the medium. EPS yield increased by $23 \%$ of control and amounted to $129.2 \mu \mathrm{g} / \mathrm{mL}$ at $1.75 \mathrm{~g} / \mathrm{L}$ of nitrogen (Figure 4 ). The positive effect of nitrogen on EPS production has been reported previously for a number of bacterial cultures [19, 20]. However, for some bacteria, such as Xanthomonas, Pseudomonas, and Rhizobium sp., cultivation under nitrogenlimiting conditions results in an increasing EPS production [21].

Increase in phosphate concentration from $0.01-5.0 \mathrm{~g} / \mathrm{L}$ also led to enhancement of growth and EPS production by Cupriavidus KPS 201 cells. Although, maximum growth was attained at $0.5 \mathrm{~g} / \mathrm{L}$ of phosphate, the optimum EPS yield $(258.7 \mu \mathrm{g} / \mathrm{mL})$ was achieved at $0.75 \mathrm{~g} / \mathrm{L}$ of phosphate. At this concentration of phosphate, more than twofold increase in EPS yield was obtained (Figure 5). However, there was no
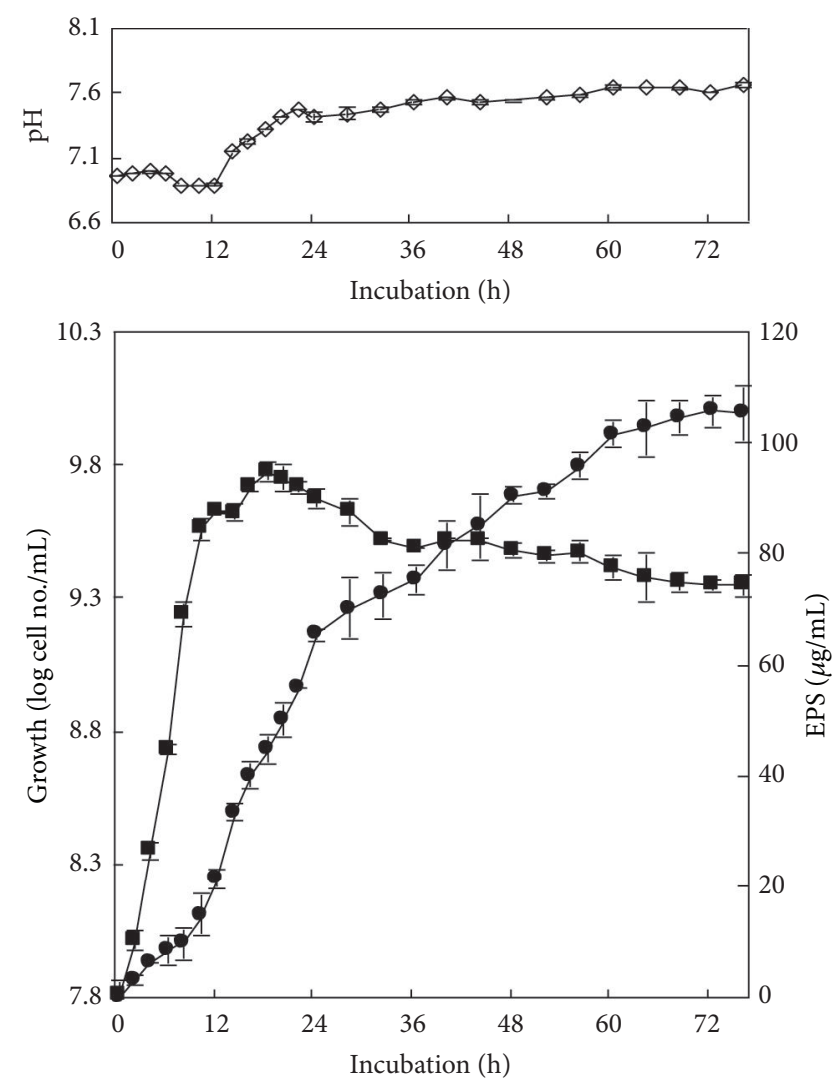

FIGURE 1: Time course of growth (--) and EPS production (- - -) by Cupriavidus KPS 201.

change in the final $\mathrm{pH}$ level of culture filtrate which remained at 7.5 to 7.7 at different phosphate concentrations. Similar reports on increase in EPS production influenced by high phosphate concentration have been reported in Sinorhizobium meliloti where $20-100 \mathrm{mM}$ phosphate enhanced the production of succinoglycan which is required for invasion of root nodules in alfalfa [22].

3.3. Effect of Heavy Metals on EPS Production. In view of the ability of Cupriavidus KPS 201 to tolerate high nickel concentrations, the effect of presence of increasing nickel concentrations on EPS production was tested. Results show that with increase in Ni concentration in the medium, EPS yield gradually declined (Figure 6) illustrating that presence of $\mathrm{Ni}$ has a negative influence on EPS production in this metal-resistant bacterium. Hence, production of EPS may not be a possible mechanism of Ni resistance in Cupriavidus KPS 201. In contrast, several bacterial isolates resistant to metals show production of high amount to exopolymers during growth in presence of heavy metals $[23,24]$ and in some cases the available metals get bound to the carbohydrate or protein moiety of the EPS remaining outside the bacterial cell [9].

3.4. Compositional Analysis of EPS. Compositional analysis of the purified EPS obtained from KPS 201 cells showed that it is a homopolymer of rhamnose. Apart from this, a small 

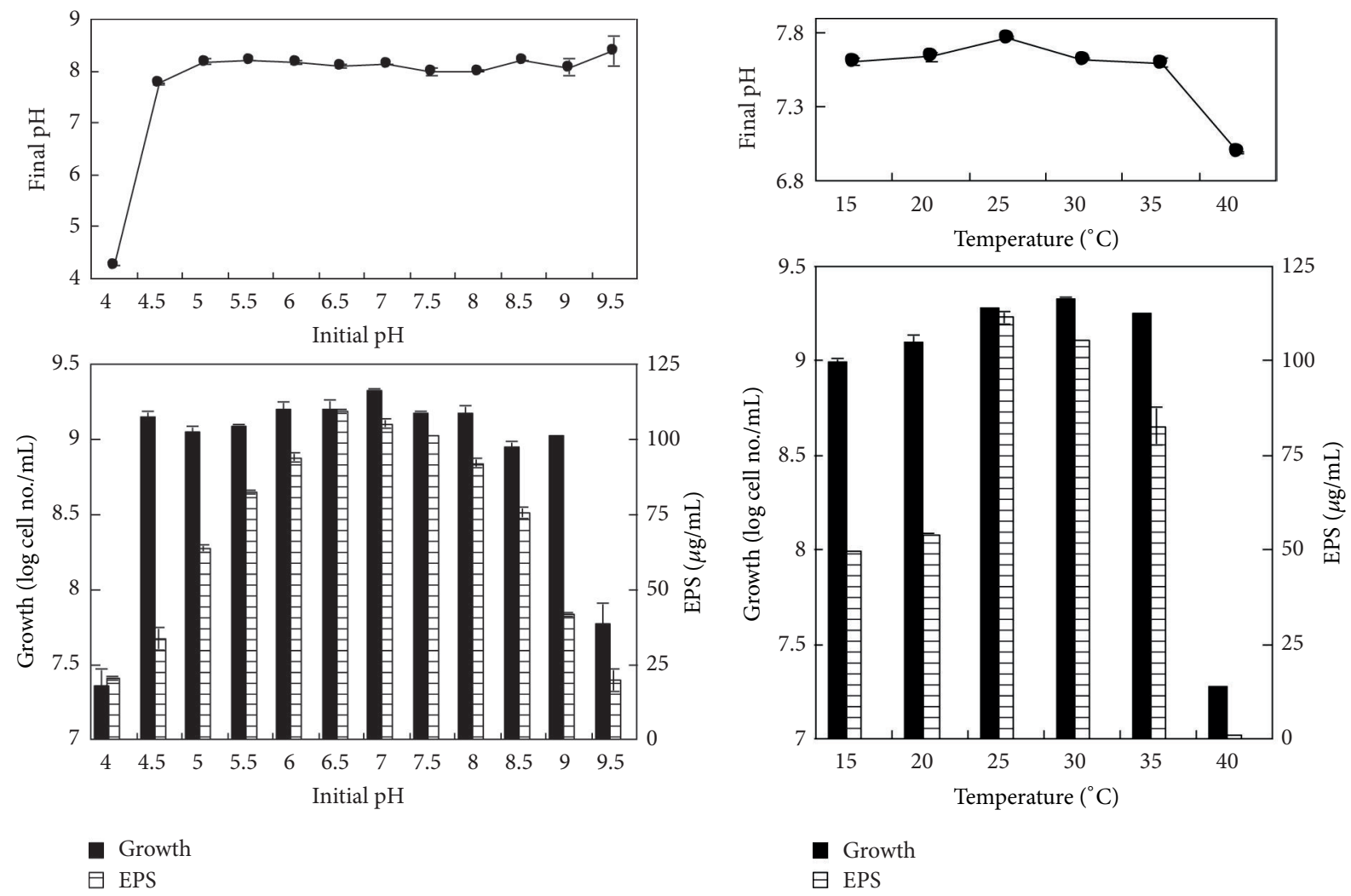

(a)

(b)

FIGURE 2: Effect of initial $\mathrm{pH}$ and temperature on growth and EPS production by Cupriavidus KPS 201.

TABLE 1: Effect of various carbon sources on growth and production of EPS by Cupriavidus KPS 201 cells.

\begin{tabular}{lccc}
\hline Carbon sources & Growth, Log no. of cells/mL & EPS, $\mu \mathrm{g} / \mathrm{mL}$ & Final pH \\
\hline Gluconate & $9.246 \pm 0.02$ & $105.63 \pm 1.21$ & $7.62 \pm 0$ \\
Glutamate & $9.320 \pm 0.03$ & $132.30 \pm 5.89$ & $8.23 \pm 0$ \\
Acetate & $8.860 \pm 0.04$ & $38.44 \pm 5.23$ & $8.09 \pm 0.05$ \\
Pyruvate & $9.106 \pm 0.02$ & $109.13 \pm 3.58$ & $7.96 \pm 0.01$ \\
Fumarate & $9.178 \pm 0.02$ & $94.76 \pm 3.17$ & $8.45 \pm 0.01$ \\
Malate & $7.287 \pm 0.02$ & 0 & $7.12 \pm 0.01$ \\
Malonate & $9.158 \pm 0.04$ & $16.18 \pm 4.28$ & $8.45 \pm 0.01$ \\
Formate & $7.348 \pm 0.06$ & 0 & $7.53 \pm 0.01$ \\
Citrate & $9.174 \pm 0.09$ & $63.70 \pm 5.35$ & $8.35 \pm 0.03$ \\
Succinate & $9.226 \pm 0.03$ & $99.69 \pm 3.09$ & $8.45 \pm 0.01$ \\
\hline
\end{tabular}

Cells were grown in Tris-minimal broth supplemented with respective carbon sources used as sodium salts at $0.4 \%$ concentration for $72 \mathrm{~h}$.

amount of uronic acid (105.5 mg/g), protein $(139.5 \mathrm{mg} / \mathrm{g})$, and nucleic acid $(1.8 \mathrm{mg} / \mathrm{g})$ was also detected. FTIR spectrum of purified EPS prepared as $\mathrm{KBr}$ pellet is illustrated in Figure 7. The spectrum shows characteristic absorption peaks at wavenumbers $3,305,2,961,1,655$, and $1,070 \mathrm{~cm}^{-1}$. The broad $\mathrm{O}-\mathrm{H}$ stretching absorption can be observed at $335.6 \mathrm{~cm}^{-1}$ and a weak C-H aliphatic stretch was observed at $2961.3 \mathrm{~cm}^{-1}$ indicating presence of lipids. The medium stretching bands at $1655,1547.2$, and $1070 \mathrm{~cm}^{-1}$ may be assigned to the $\mathrm{N}-\mathrm{H}$ bending and $\mathrm{C}-\mathrm{N}$ amine group of proteins. The weak bands between 1300 and 900 may be consigned to carbohydrates and nucleic acids [25].

3.5. Visualization of EPS with Fluorescently Labeled Lectins. EPSs are known to be the main components behind structural and functional properties of bacterial biofilms. Fluorescent microscopy allows nondestructive visualization of the biofilm EPS which get disturbed during isolation and extraction process. In the present study, glass surface was used as the substratum for biofilm development. The DNA and EPS of 


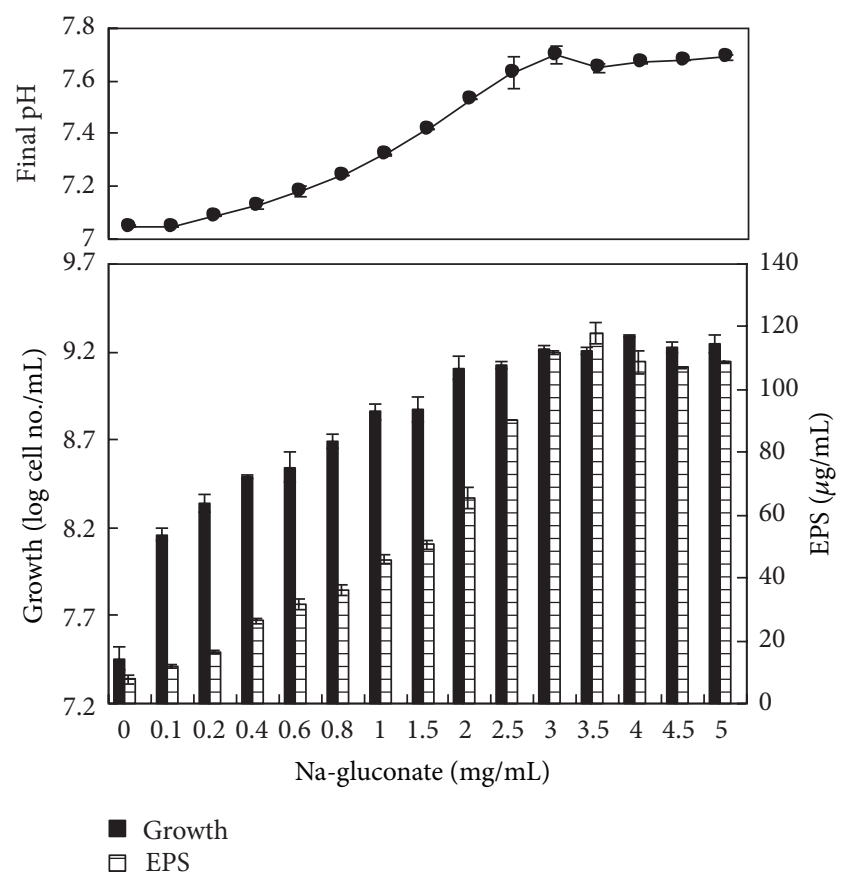

FIGURE 3: Effect of gluconate concentration on growth and EPS production by Cupriavidus KPS 201.
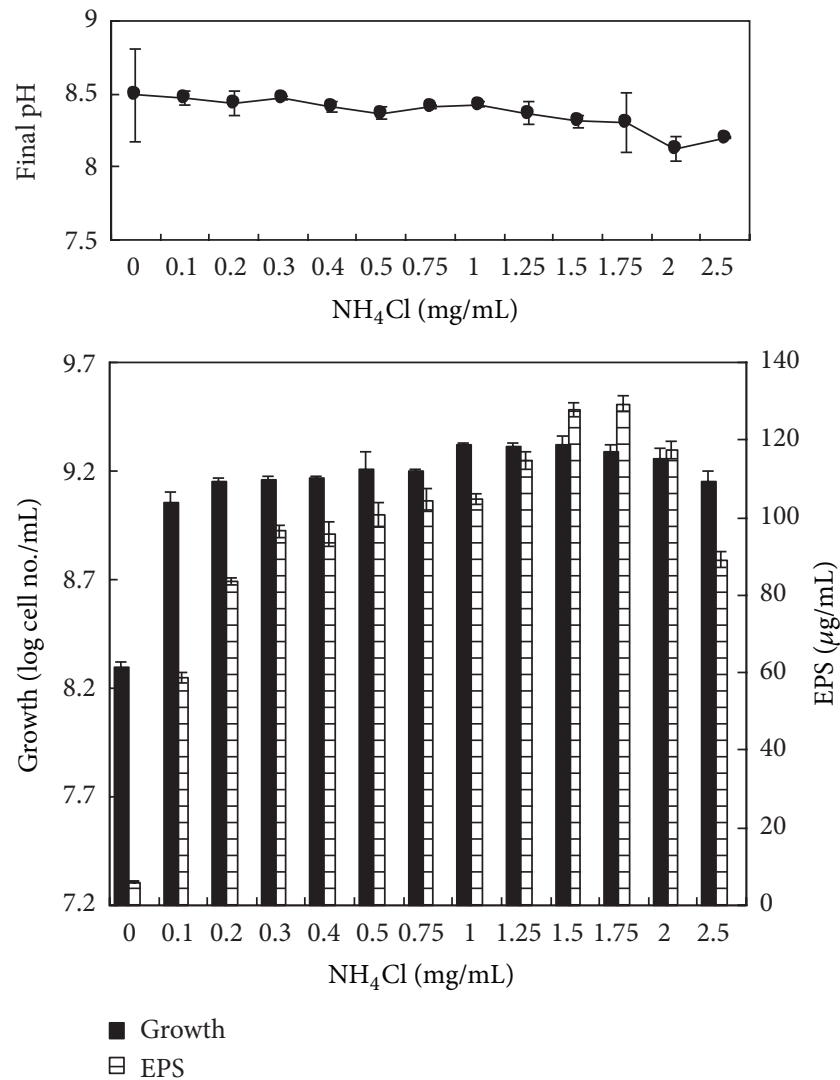

FIGURE 4: Effect of nitrogen concentration on growth and EPS production by Cupriavidus KPS 201.
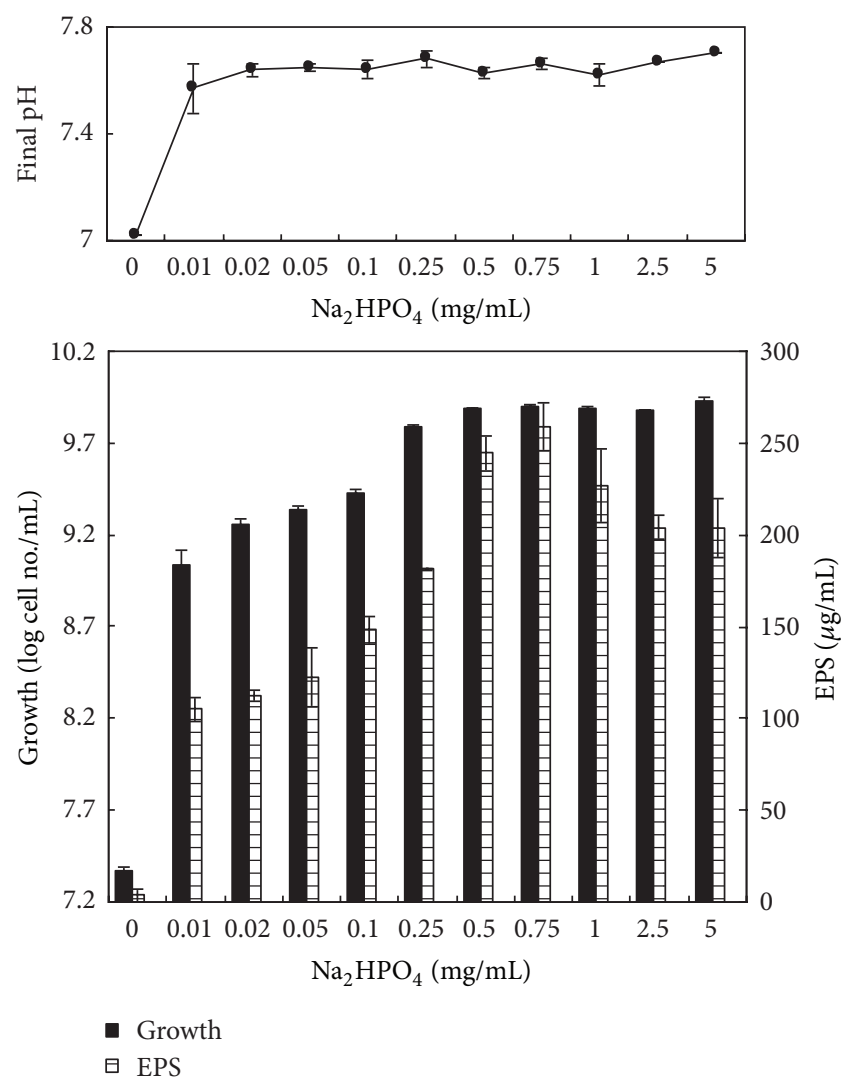

FIGURE 5: Effect of phosphate concentration on growth and EPS production by Cupriavidus KPS 201.
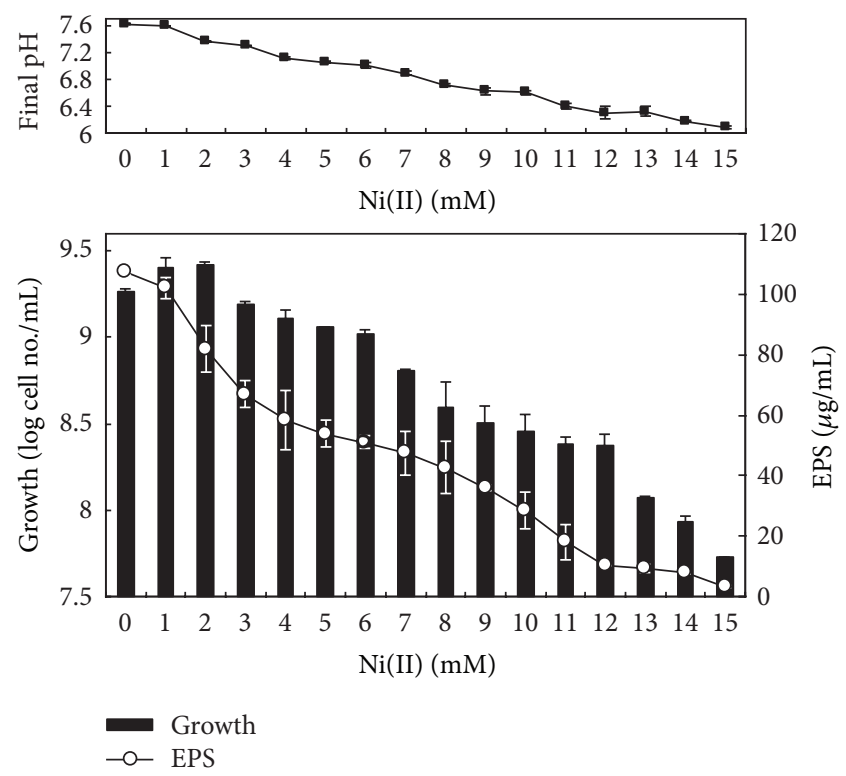

FIGURE 6: Effect of increasing Ni concentration on growth and EPS production by Cupriavidus KPS 201. 


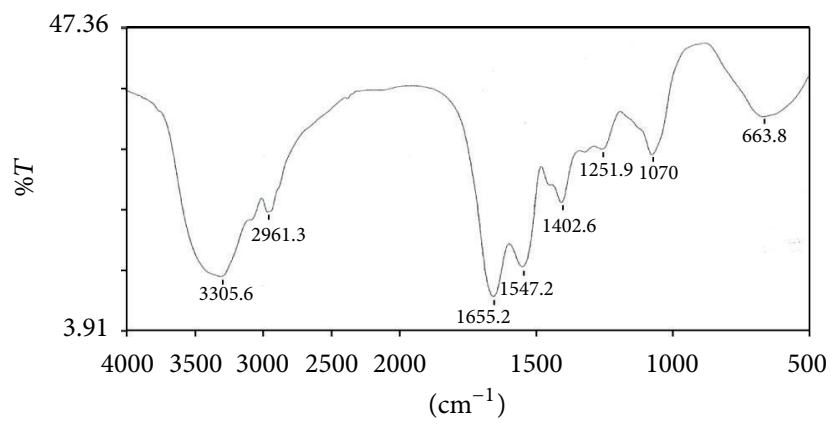

FIGURE 7: Fourier transform infra red spectroscopy of purified EPS from Cupriavidus KPS 201.

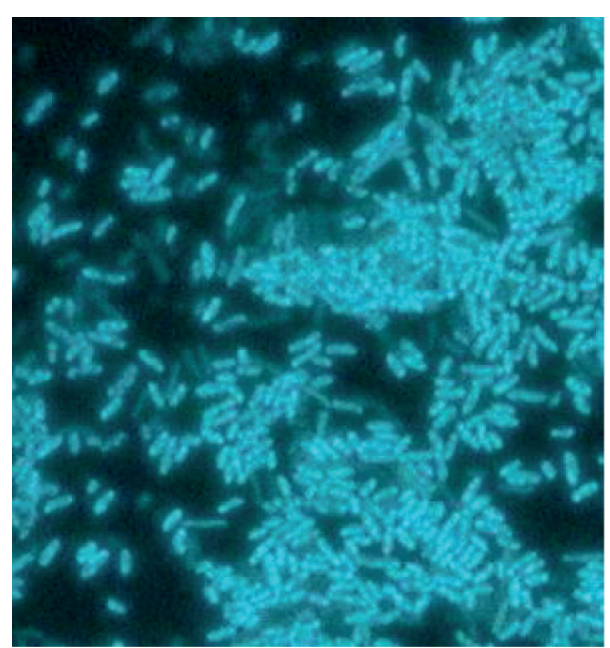

(a)

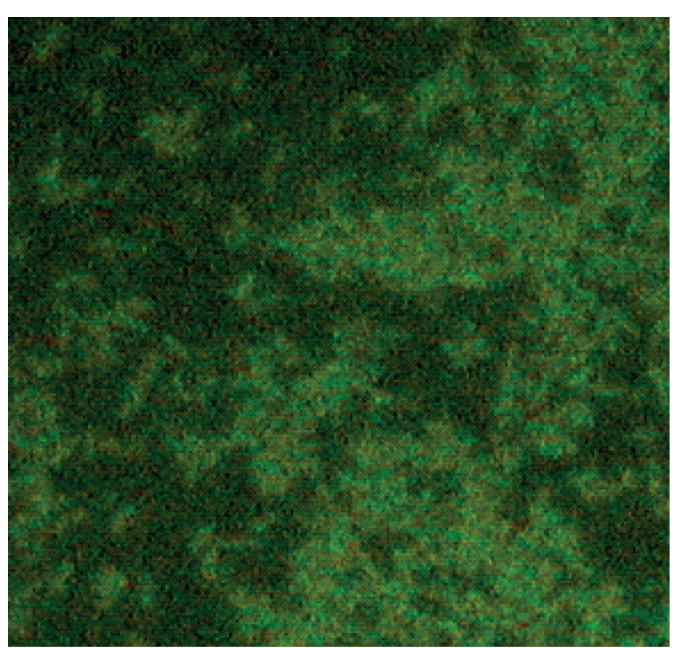

(b)

FIGURE 8: Visualization of bacterial cells and biofilm EPS by staining with DAPI (a) and fluorescently labeled lectin concanavalin A (b), respectively by epifluorescence microscopy.

bacterial cells (KPS 201) were stained with 4',6-diamidino2-phenylindol (DAPI) and the fluorescein isothiocyanatelabeled lectin concanavalin A (FITC-ConA), respectively, and visualized by epifluorescence microscopy (Figure 8 ). The use of fluorescently labeled lectins allowed the microscopically in situ detection of EPS (in green filter) and their distribution in pure culture biofilms (cells visualized under blue filter) of different bacteria [26].

\section{Conclusion}

The present study demonstrates growth associated production of extracellular polymeric substances (EPS) by serpentine rhizobacterium, Cupriavidus pauculus KPS 201, and its role in the biofilm formation. Optimization of cultural conditions shows that EPS production is dependent on temperature, initial $\mathrm{pH}$, and concentrations of carbon, nitrogen, and phosphate in the medium. EPS production, however, is negatively influenced by the presence of nickel in the growth medium revealing that EPS has no role in conferring high degree of resistance to nickel in the serpentine isolate. Nevertheless, the interaction of purified polymer with heavy metals needs to be studied extensively for bioremediation approaches.

\section{Acknowledgments}

The authors thank Professor Wolfgang Sand, University of Hamburg, Germany (presently in University of Duisburg, Germany) for providing necessary help and suggestion in this research. The authors acknowledge Prof. A. N. Patra, Department of Chemistry, University of Calcutta, Kolkata, for FTIR spectroscopy analysis. Financial support to A. Pal from German Academic Exchange Service (DAAD), Bonn, Germany, is duly acknowledged.

\section{References}

[1] J. Wingender, T. R. Neu, and H. C. Flemming, "What are bacterial extracellular polymeric substances?" in Microbial Extracellular Polymeric Substances, J. Wingender, T. R. Neu, and H. C. Flemming, Eds., pp. 1-20, Springer, Berlin, Germany, 1999.

[2] G. P. Sheng, H. Q. Yu, and Z. Yue, "Factors influencing the production of extracellular polymeric substances by 
Rhodopseudomonas acidophila," International Biodeterioration and Biodegradation, vol. 58, no. 2, pp. 89-93, 2006.

[3] I. Llamas, H. Amjres, J. A. Mata, E. Quesada, and V. Bejar, "The potential biotechnological applications of the exopolysaccharide produced by the halophilic bacterium Halomonas almeriensis," Molecules, vol. 17, no. 6, pp. 7103-7120, 2012.

[4] M. Feng, X. Chen, C. Li, R. Nurgul, and M. Dong, "Isolation and identification of an exopolysaccharide-producing lactic acid bacterium strain from chinese paocai and biosorption of $\mathrm{Pb}$ (II) by its exopolysaccharide," Journal of Food Science, vol. 77, no. 6, pp. T111-T117, 2012.

[5] C. S. Laspidou and B. E. Rittmann, "A unified theory for extracellular polymeric substances, soluble microbial products, and active and inert biomass," Water Research, vol. 36, no. 11, pp. 2711-2720, 2002.

[6] Y. Liu and J.-H. Tay, "State of the art of biogranulation technology for wastewater treatment," Biotechnology Advances, vol. 22, no. 7, pp. 533-563, 2004.

[7] H.-C. Flemming, "Sorption sites in biofilms," Water Science and Technology, vol. 32, no. 8, pp. 27-33, 1995.

[8] H. Horn and E. Morgenroth, "Transport of oxygen, sodium chloride, and sodium nitrate in biofilms," Chemical Engineering Science, vol. 61, no. 5, pp. 1347-1356, 2006.

[9] D. L. Gutnick and H. Bach, "Engineering bacterial biopolymers for the biosorption of heavy metals; new products and novel formulations," Applied Microbiology and Biotechnology, vol. 54, no. 4, pp. 451-460, 2000.

[10] A. Pal and A. K. Paul, "Microbial extracellular polymeric substances: central elements in heavy metal bioremediation," Indian Journal of Microbiology, vol. 48, no. 1, pp. 49-64, 2008.

[11] A. Pal, G. Wauters, and A. K. Paul, "Nickel tolerance and accumulation by bacteria from rhizosphere of nickel hyperaccumulators in serpentine soil ecosystem of Andaman, India," Plant and Soil, vol. 293, no. 1-2, pp. 37-48, 2007.

[12] A. Pal and A. K. Paul, "Accumulation of polyhydroxyalkanoates by rhizobacteria underneath nickel-hyperaccumulators from serpentine ecosystem," Journal of Polymers and the Environment, vol. 20, no. 1, pp. 10-16, 2012.

[13] M. Dubois, K. A. Gilles, J. K. Hamilton, P. A. Rebers, and F. Smith, "Colorimetric method for determination of sugars and related substances," Analytical Chemistry, vol. 28, no. 3, pp. 350356, 1956.

[14] O. H. Lowry, N. J. Resebrough, A. L. Farr, and R. J. Randall, "Protein measurement with the Folin phenol reagent," The Journal of Biological Chemistry, vol. 193, no. 1, pp. 265-275, 1951.

[15] N. Blumenkrantz and G. Asboe Hansen, "New method for quantitative determination of uronic acids," Analytical Biochemistry, vol. 54, no. 2, pp. 484-489, 1973.

[16] R. K. Sizemore, J. J. Caldwell, and A. S. Kendrick, "Alternate Gram staining technique using a fluorescent lectin," Applied and Environmental Microbiology, vol. 56, no. 7, pp. 2245-2247, 1990.

[17] J. Wang and H.-Q. Yu, "Biosynthesis of polyhydroxybutyrate (PHB) and extracellular polymeric substances (EPS) by Ralstonia eutropha ATCC 17699 in batch cultures," Applied Microbiology and Biotechnology, vol. 75, no. 4, pp. 871-878, 2007.

[18] R. Gharzouli, A. Benamhmed, Y. Benhizia, and A. Benguedouar, "Influence of carbon source on the production of exopolysacharides by Rhizobium sullae and on the nodulation of Hedysarum coronarium L. legume," African Journal of Microbiology Research, vol. 6, pp. 5940-5946, 2012.
[19] S. A. Kimmel, R. F. Roberts, and G. R. Ziegler, "Optimization of exopolysaccharide production by Lactobacillus delbrueckii subsp. bulgaricus RR grown in a semidefined medium," Applied and Environmental Microbiology, vol. 64, no. 2, pp. 659-664, 1998.

[20] B. Degeest and L. de Vuyst, "Indication that the nitrogen source influences both amount and size of exopolysaccharides produced by Streptococcus thermophilus LY03 and modelling of the bacterial growth and exopolysaccharide production in a complex medium," Applied and Environmental Microbiology, vol. 65, no. 7, pp. 2863-2870, 1999.

[21] G.-P. Sheng and H.-Q. Yu, "Relationship between the extracellular polymeric substances and surface characteristics of Rhodopseudomonas acidophila," Applied Microbiology and Biotechnology, vol. 72, no. 1, pp. 126-131, 2006.

[22] K. E. Mendrygal and J. E. González, "Environmental regulation of exopolysaccharide production in Sinorhizobium meliloti," Journal of Bacteriology, vol. 182, no. 3, pp. 599-606, 2000.

[23] S.-Y. Kim, J.-H. Kim, C.-J. Kim, and D.-K. Oh, "Metal adsorption of the polysaccharide produced from Methylobacterium organophilum," Biotechnology Letters, vol. 18, no. 10, pp. 11611164, 1996.

[24] S. K. Kazy, P. Sar, S. P. Singh, A. K. Sen, and S. F. D’Souza, "Extracellular polysaccharides of a copper-sensitive and a copperresistant Pseudomonas aeruginosa strain: synthesis, chemical nature and copper binding," World Journal of Microbiology and Biotechnology, vol. 18, no. 6, pp. 583-588, 2002.

[25] Y. Jiao, G. D. Cody, A. K. Harding et al., "Characterization of extracellular polymeric substances from acidophilic microbial biofilms," Applied and Environmental Microbiology, vol. 76, no. 9, pp. 2916-2922, 2010.

[26] M. Strathmann, J. Wingender, and H.-C. Flemming, "Application of fluorescently labelled lectins for the visualization and biochemical characterization of polysaccharides in biofilms of Pseudomonas aeruginosa," Journal of Microbiological Methods, vol. 50, no. 3, pp. 237-248, 2002. 

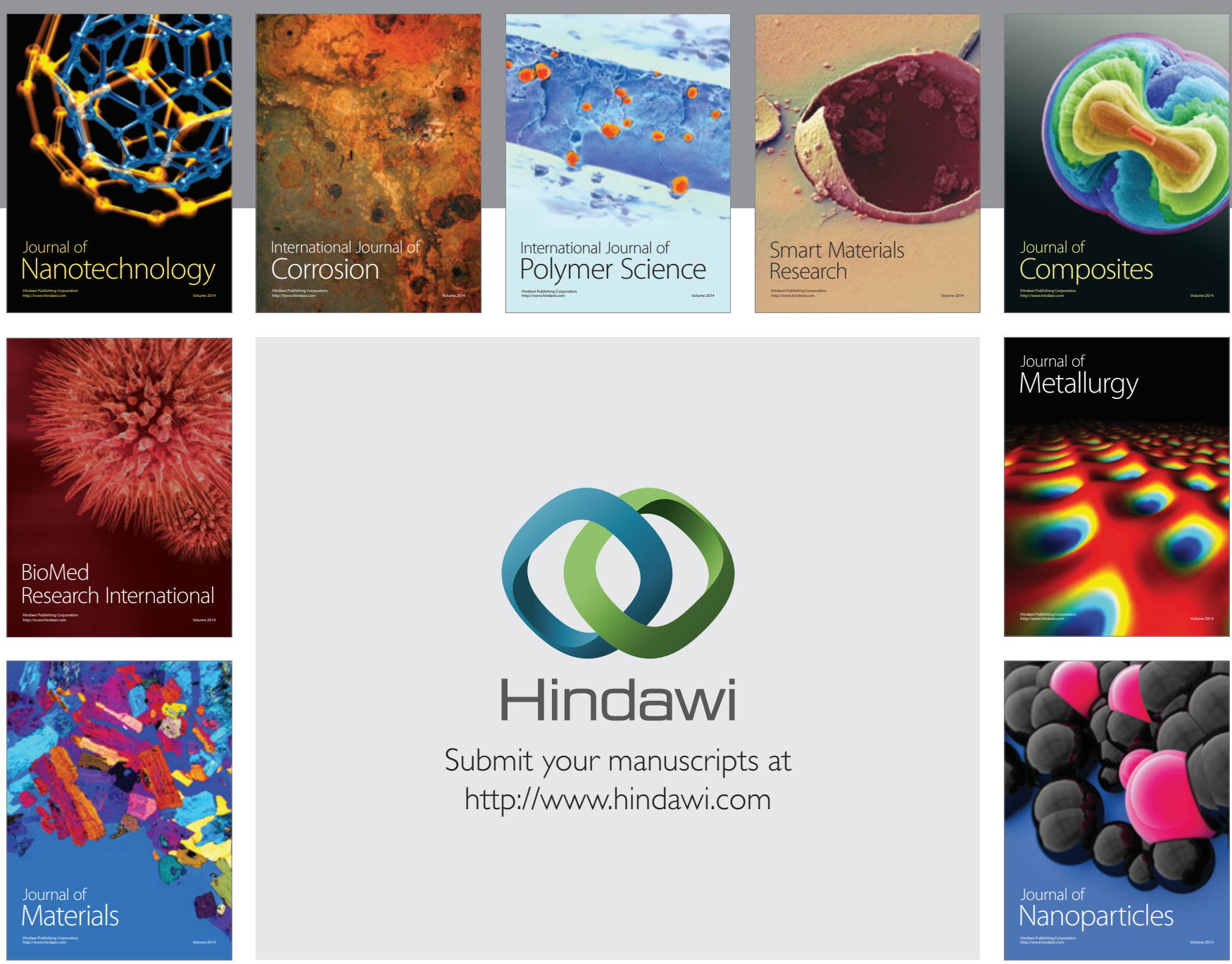

Submit your manuscripts at http://www.hindawi.com
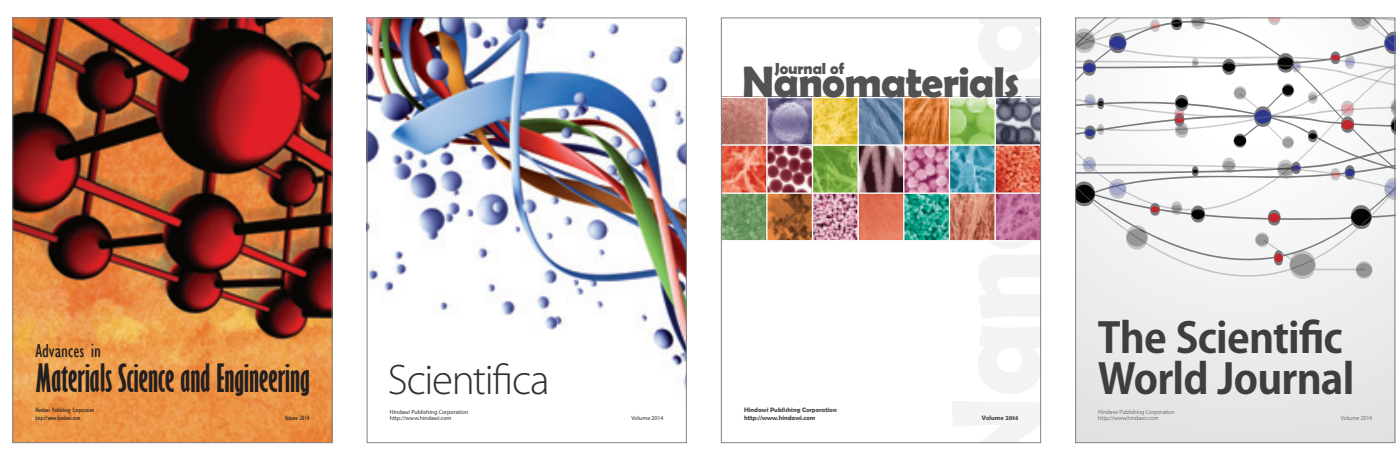

\section{The Scientific World Journal}
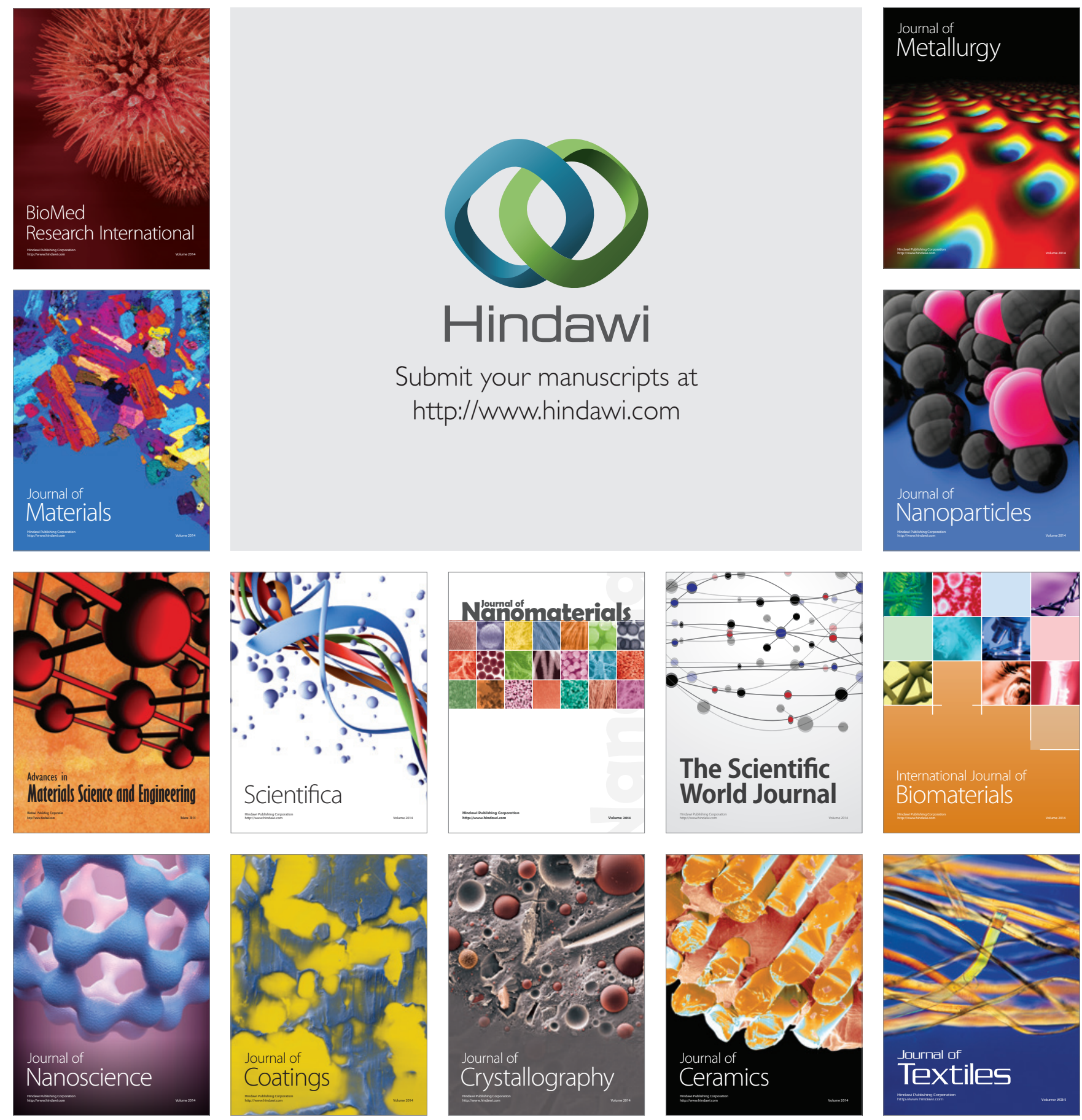